\title{
Growth, Phenology, Yield and Nutrient Uptake of Sweet Corn as Influenced by Cultivars and Planting Times under Irrigated Subtropics of Shiwalik Foot Hills
}

\author{
Monika Banotra ${ }^{*}$, B.C. Sharma, Brij Nandan, Akhil Verma, I.A. Shah, \\ Rakesh Kumar, Vikas Gupta and Tundup Namgial
}

Department of Agronomy, Sher-e-Kashmir University of Agricultural

Sciences and Technology-Jammu-180009, India

*Corresponding author

\section{A B S T R A C T}

The field experiment was conducted during summer season of 2013 under irrigated subtropics Shiwalik foot hills to study the effect of different cultivars and planting times of sweet corn on sandy clay loam soil, at the Research Farm of Division of Agronomy, Shere-Kashmir University of Agricultural Sciences and Technology of Jammu. The treatments include three sweet corn cultivars (Misthi, Sugar-75 and Gold star) and six planting times (29 March, 15 April, 30 April, 15 May, 30 May and 19 June) in split plot design. Results revealed that different cultivars "Misthi, Sugar-75 and Gold star" did not differ significantly from one another with regard to plant height, leaf area index and dry matter

Keywords

Sweet corn,

Cultivars,

Planting time.

\section{Article Info}

Accepted:

26 September 2017

Available Online:

10 October 2017 accumulation, however, cultivar Misthi recorded numerically higher values of all these parameters over Sugar-75 and Gold star. Similarly, cultivar Misthi registered its numerical superiority in all the phenological parameters like yield, uptake of nitrogen, phosphorus and potassium as well as significantly superior in days taken to $50 \%$ tasseling, cob girth, number of grains/row, number of grains/cob row and phosphorus uptake in stover and potassium uptake in grains. Among the six planting times, 29 March, 15April, 30 April, 15 May, 30 May and 19 June; the crop sown on April 15, March 29 and April 30 recorded statistically similar but significantly more plant height, leaf area index, dry matter accumulation, cob length, number of grain rows/cob, number of cobs /plant, number of grains/cob and grain yield at maturity, nitrogen uptake in grains, phosphorus and potassium uptake in both grain and stover yields than the crop sown on 15 May and onwards. The crop sown on 29 March took significantly more days to attain $50 \%$ tasseling and silking. Therefore, cultivar Misthi has been adjudged as the best cultivar and the period from 29 March to 30 April as the optimum sowing window with 15 April as appropriate sowing time for judicious utilization of applied resources for optimization of yields under sub-tropical Shiwalik foot hills.

\section{Introduction}

Growth and development of crops are known to be influenced by multiple factors and amongst them selection of cultivars for a given set of environment is one of the major aspects besides soil fertility, temperature regimes, solar radiations, irrigation etc. which play a very important role in exploiting good crop growth and development. Several hybrid 
and composite varieties of different yield potentials, quality and of varying maturity groups of different crops developed and released on the basis of different agro climatic conditions are tested for cultivation to assess their performance under varied environmental situations. Varietal differences in growth characteristics of maize have been reported by Ayub et al., (1998) and Ramankutty et al., (2002). Planting time is one of the key points in crop management to optimizing productivity. Crops response differently to different planting date's Sweet corn due to its short time growth could be planted in several sowing dates. Planting at proper time is important components of cropping system. Earliest planting of corn is preferable because of utilization of the entire growing season, achieving physiological maturity before frost, and proper drying, thereby increasing profit through reduced drying costs and allowing greater profit margin. Planting time should be scheduled such that the growth stages do not coincide with mid-summer droughts. Out of management aspects of growing maize crop (Cultivar selection, plant density, amount and timing of fertilizers etc.) planting date is probably the most subject of variation because of the very great differences in weather at planting time between seasons and within the range of climates but year to year variation in plant establishment, pest and disease incidence make it difficult to predict optimum planting dates for maize crops (Oktem, 2000).

Under different planting date, crop sown pass through each developmental stage at different times and therefore, under different environmental condition (especially photoperiod and temperature), thus any one of the development stage which determine the components of yield could conceivably occur under more or less favourable conditions in late sown crops as reported by Swanson and Wilhelm (1996).In practice recommended dates are normally drawn up from the results of long running series of agronomic experiments which gave mean planting dates highest together with realistic estimates of expected yield penalties for each week of delay in planting time. The planting date of sweet corn not only effects seed germination, but the whole phenological stages will be impressed by planting time as reported by Mokhtarpour et al., (2013).

\section{Materials and Methods}

A field experiment was conducted during summer 2013 at the Research Farm of Division of Agronomy, Sher-e-Kashmir University of Agricultural Sciences and Technology of-Jammu (Jammu and Kashmir) situated at $32^{\circ} 39^{\prime} \mathrm{N}$ latitude and $74^{0} 53^{\prime} \mathrm{E}$ longitude at an elevation of 332 meter above mean sea level. The research farm of the Division of Agronomy comes under the subtropical-irrigated Shiwalik foothill zone. The soil of the experimental site was sandy clay loam in texture. The soil was slightly alkaline in $\mathrm{pH}$ (7.31) with electrical conductivity in the safer range $\left(0.19 \mathrm{dsm}^{-1}\right)$, low in organic carbon (0.37) and available $\mathrm{N}$ $(245.78 \mathrm{~kg} / \mathrm{ha})$ but medium in available phosphorus (13.26 kg/ha) and potassium $(144.26 \mathrm{~kg} / \mathrm{ha})$. The monthly rainfall average rainfall during the crop growing periods in 2013 ranged from $4.6 \mathrm{~mm}$ in April to 496.7 $\mathrm{mm}$ in August. The total rainfall received during the crop growing periods from April to September was $1014.7 \mathrm{~mm}$ which was 13.38 per cent more from its normal rain fall value. Sweet corn cultivars planted on 29 March experienced total rainfall of $268 \mathrm{~mm}$ in17 rainy days up to maturity while 15 April, 30 April, 15 May, 30 May and 19 June planted crop received total rainfall of $450.3 \mathrm{~mm}$, $794 \mathrm{~mm}, 874.5 \mathrm{~mm}, 967.4 \mathrm{~mm}, 894.5 \mathrm{~mm}$ in $26,34,38,42$ and 38 rainy days during their respective crop periods. As regards the total rainfall trends for different planting dates, the 
highest rainfall $967.4 \mathrm{~mm}$ was experienced in the crop planted on 30 May planting date, while as the lowest total rainfall of $268 \mathrm{~mm}$ was recorded 29 March, planting date respectively. The experiment was laid out in split plot design with three replications and comprising eighteen treatment combinations with three sweet corn Misthi, Sugar-75 and Gold star as main plot and six planting times 29 March, 15April, 30 April, 15 May, 30 May and 19 June in subplots. The net plot area was $3.6 \times 2.20 \mathrm{~m}$ with spacing $60 \times 20 \mathrm{~cm}$.

The recommended doses of $\mathrm{N}(120 \mathrm{~kg}), \mathrm{P}_{2} \mathrm{O}_{5}$ $(60 \mathrm{~kg})$ and $\mathrm{K}_{2} \mathrm{O}(40 \mathrm{~kg})$ were applied in the form of urea, diammonium phosphate and muriate of potash, respectively. Half of the dose of $\mathrm{N}$ and whole amount of $\mathrm{P}$ and $\mathrm{K}$ was applied as basal and the remaining half dose of nitrogen was applied in two equal splits at knee high and pre-tasseling stages. Plant height, leaf area index, dry matter accumulation (g/plant) were recorded at periodic intervals and at harvest. Days taken to emergence were calculated by counting the days from sowing to appearance of first plant just above the ground.

Emergence count (\%) can be calculated by the formula:

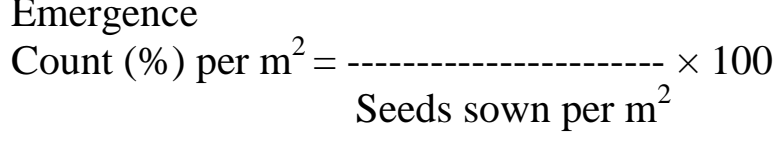

The phenological stages viz., tasseling, silking and maturity were identified according to the procedure specified by Ritchie et al., (1989). Cob characteristics like length of cob, cob girth, number of grain rows per cob, number of grains per cob were calculated by randomly selected ten cobs from each treat mental plot. Grain yield from each net plot were weighed separately and finally converted into (t/ha) by multiplying with conversion factor.
Uptake of nitrogen, phosphorus, potassium by grain, stover were calculated by multiplying the per cent nutrient content with their respective dry matter of grain and stover. The nutrient content so obtained from grain and stover were added to work out the total uptake of nutrients.

The standard formula for calculating nutrient uptake is given below:

Nutrient content (per cent) $\times$ dry matter accumulation $(\mathrm{kg} / \mathrm{ha})$

Nutrient uptake $(\mathrm{kg} / \mathrm{ha})=$ 100

\section{Results and Discussion}

\section{Growth parameters}

\section{Plant height}

Cultivars did not put forth any significant effect on plant height even though the cultivar Misthi produced taller plants followed by Sugar-75 and Gold star with 70.21, 68.80and $67.89 \mathrm{~cm}$ of plant height recorded at 30 DAS, respectively. The subsequent increase in plant height with the increase in age of the plants as observed at 60,90 DAS and at harvest did not show any change in plant height trends and had followed the similar order as was recorded at 30 DAS. Leaf area index of a crop indicates its photosynthetic potential or the level of its dry matter accumulation. Higher is the leaf area index. The higher will be dry matter accumulation potential of the crop and vice versa. The leaf area was low in the beginning i.e.at $30 \mathrm{DAS}$, with non-significant variations among the different sweet corn cultivars and planting times. It increased progressively with the advancement of the growth period and attained its maximum value at 60 DAS and thereafter it showed a decline at 90 DAS and harvest maturity. Though, non-significant differences were 
recorded for dry matter accumulation per plant at all the four stages among all the sweet corn cultivars but numerically, the higher dry matter accumulation was recorded for cultivar Misthi (146.19g) followed by Sugar-75 (145.33g) and Gold star (142.70g) at harvest maturity respectively. This variation might be due to difference in vigorous vegetative growth of sweet corn cultivars which was attributed to difference in genetic character of the cultivars. Similar results were also reported by Ramezani et al., (2011).

Among the planting time April 15 planted crop recorded maximum plant height $(211.42 \mathrm{~cm})$ followed by March 29 (203.37 $\mathrm{cm})$ and April $30(200.87 \mathrm{~cm})$ sowings which were found to be statistically at par with each other and significantly superior to May 15 $(174.12 \mathrm{~cm})$, May $30(163.47 \mathrm{~cm})$ and June 19 $(108.72 \mathrm{~cm})$ planted crops. The plantings of May 15 and May 30 did not differ statistically from one another and 19 June sown crop recorded significantly smaller plant heights from all the other planting dates. Leaf area index of sweet corn was significantly influenced by planting dates as observed at 60,90 DAS and at harvest maturity whereas it recorded non-significant differences at 30DAS. At 60 DAS crop sown on April 15 recorded maximum leaf area index (4.38) which was found to be statistically at par in leaf area index of 4.28 and4.25recorded with March 29 and April 30 planting dates, respectively. All these planting dates recorded significantly higher leaf area index than May 15, May 30 and June 19 plantings. At 90 DAS, the highest dry matter accumulation of $88.40 \mathrm{~g}$ per plant was recorded with April 15 planting and this was found statistically at par with the dry matter accumulation of $85.91 \mathrm{~g}$ per plant and $80.37 \mathrm{~g}$ per plant recorded with March 29 and April 30 planting dates, respectively. Dry matter accumulation recorded in crop sown on May 15 was found statistically at par with May 30 sown crop but significantly superior than crop sown on June 19. Dry matter accumulation at 30, 60 DAS and at harvest maturity also give similar trend under all the planting times. The possible reason for these improvements in growth parameters during the early sown crops might be attributed to excellent weather condition observed during March to April which includes a combination of high solar radiation and average air temperature of $30^{\circ} \mathrm{C}$ during the growing seasons which were considered optimal for sweet corn growth. The favourable climatic conditions during these planting dates help in proper plant build up and resulted in overall better crop growth and vigour due to which earlier sown crop had a longer life span. Further, the possible reasons for obtaining smaller plant height with lesser leaf area index and low dry matter production during 30 May and 19 June was might be due to fall in air temperature accompanied with higher rainfall and stagnation of water which drastically affected the crop growth during growing season of these planting time which resulted in poor plant growth. Thus the plants do not get adequate opportunity for photosynthesis and other physiological processes during these periods of crop growth and resulted in shortening of the growing cycle and thus responsible for in reduction of plant height and leaf area index which in turn also decreases dry matter accumulation per plant of sweet corn in these planting dates Ramachandrudu et al., (2013)

\section{Phenological stages}

\section{Emergence count}

Sweet corn cultivars had significantly influenced the per cent emergence count of plants. It is evident from the data presented in table 2 that the cultivar Misthi though statistically at par with Gold star (73.36 \%) recorded significantly higher per cent emergence count of plants $(80.03 \%)$ as 
compared to Sugar-75 (66.69 \%) and the cultivar Sugar-75 in turn also recorded statistically comparable per cent emergence count of plants with Gold star. Significant variation in per cent emergence count was recorded between different cultivars of sweet corn under different planting dates. The highest per cent emergence count of plants $(82.69 \%)$ was recorded with April 15 planted crop being statistically at par with March 29 (81.36\%), April $30(78.69 \%)$ and May 30 (76.69 \%) planting dates and all these planting dates were found significantly superior than May 15 (71.36\%) followed by June19 (49.35\%) planted crops and these latter two cultivars in turn also June 19 planted crop recorded lower values of this parameter might be an indicative of the fact that combination of low soil temperature and high soil water content during sowing period resulted in poor maize establishment. Similar findings about the influence of low soil temperature and high water content on maize emergence count were also reported by Kara (2011).

\section{Days to emergence}

All three sweet corn cultivars took statistically similar number of days to emergence even though some numerical differences have been recorded among themselves where in cultivar Gold star with 5.38 days took more time to emergence followed by Misthi and Sugar-75 each with 4.66 days. The number of days taken to emergence was found maximum with cultivar Gold star which may be ascribed to the fact that Gold star is a bold seeded variety with hard seed coat coupled with low starch concentration in sweet corn kernels which resulted in reduction in energy reserves for emergence and may needs more favourable germination conditions like water and nutrition for better physiological processes for germination than other two cultivars Misthi and Sugar-75 which contain high starch content under investigation. The carbohydrate stored in the endosperm of seed, which was the source of reserve food for the sweet corn till it become autotrophic. During the germination process the reserve food material in seed, starch undergo biochemical changes to get converted in to simple soluble carbohydrates which get easily translocated to the growing points for germination i.e. formation of radical and plumule. Therefore more is the reserve food material in the seed faster will be the conversion of starch into simple carbohydrates and lesser days are taken for the emergence of corn Douglass et al., (1993) and Znidarcic et al., (2008).

Significant effect of planting times was noticed on days to emergence of sweet corn. March 29 planted crop took significantly higher days (5.77 days) to emerge as compared to other planting times. It was followed by the crop planted on 30 of May which took statistically similar days to emergence (5.22 days) with that of crop sown on April 15 with 5.00 days and this in turn was found statistically at par with the crop sown on $30^{\text {th }}$ of April which took 4.66 days. The June 19 sown crop took significantly less (4.44days) but statistically similar days to emergence as recorded with the crops sown on May 15 with 4.33 days and 30 of April.

The decrease in days taken to emergence from 29 March onwards might have been due to variation in soil and environmental behaviours like moisture and temperature during the planting dates that influence the germination and emergence. Low soil temperature at 29 March planting time slows down the biochemical process occurring inside the seed which provides energy for the germination of corn by forming radicle and plumule might be the responsible for slowed emergence in the sweet corn Kwabiah (2003), Garcia et al., (2009) 


\section{Days to 50 per cent tasseling and silking}

Among the different sweet corn cultivars, the cultivar Misthi took maximum days (54.83 days) followed by Sugar -75 (54.47 days) to attain 50 per cent tasseling which were statistically at par but significantly higher than cultivar Gold star which took minimum days (53.74 days) to attain this stage where as sweet corn cultivars did not show any statistically difference with regard to days taken to achieve 50 per cent silking. Numerically, the cultivar Misthi took maximum days (60.71 days) followed by cultivar Sugar-75 (60.32 days) and Gold star (60.21 days) to attain 50 per cent silking in decreasing order of number of days, respectively. This variation in the number of days taken to tasseling and silking was due to genetic variation of the different sweet corn cultivars Khan et al., (2009).

Among the different planting times, 29 March sown crop took maximum days (56.31 days) to acquire 50 per cent tasselling and this was statistically at par in days taken by the crop with April 15 (55.62 days) and April 30 (55.45 days) sown crops to get to this stage.May 15 sown crop with 53.35 days was found statistically at par with May 30 sown crop which took 53.15 days to obtain 50 per cent tasselling and was significantly superior in days than June $19^{\text {th }}$ sown crop (52.22 days) which recorded significantly less days from all the sowing dates to manage this stage.

A similar trend as was observed for achieving 50 per cent tasseling at different planting dates was recorded for 50 per cent silking also. March 29 planted crop took maximum days (61.93 days) which were statistically similar with April 15 (61.79 days) and April 30 (61.50 days) planting dates whereas May 15 sown crop with 59.62 days was found statistically at par with May 30 sown crop (59.60 days) and these latter two dates of sowings were also established to be statistically different than June $19^{\text {th }}$ sown crop which took 58.00 days to attain 50 per cent silking. June 19 sown crop recorded significantly less days from all the sowing dates to manage these stages might be due to the reason that the highest rainfall of 309.4 $\mathrm{mm}$ (30.45 per cent of the total rainfall) was received during the silking stage of the sixth planting date, which have resulted in the shedding of pollens before appearance of silks and thus effects the fertilization process. The receipt of more rainfall as compared to the seasonal average in the crop growing seasons accompanied with water logging condition which might have affected the overall performance of the sweet corn in the June 19 sown crop whereas earlier sown crop completed their vegetative phase in favourable climate conditions and ultimately started tasseling and silking earlier. Variation in phenophases might be due to the differences in photoperiod and temperature among sowing dates (Nielsen et al., (2002) and Khan et al., (2011).

\section{Days taken up to maturity}

Cultivar Gold star took minimum 91.55 days to reach harvest maturity stage which were significantly less from Sugar-75 and Misthi with 93.10 days and 94.24 respectively, which in turn also differed significantly from one another. This might be due to the reason that different crop cultivars take their normal time to develop different vegetative and reproductive structure and attain maturity. These results were akin to that of Otegui et al., (1995).

Among the different planting times, the maximum number of days taken to arrive at harvest and physiological maturity followed the similar trend as was recorded for 50 per cent tasseling and silking in different planting dates. Maximum of 94.67 days taken by the 
crop to reach harvest maturity were recorded with March 29 sown crop which was statistically at par with April 15 and April 30 sown crops with 94.57 days and 94.26 days, respectively. May 15 and May 30 sown crop were found statistically at par with each other in days for acquiring harvest 92.47 days and 92.41 days and sweet corn crop planted on these two latter dates took statistically more days than June 19 planting which took 89.40 days to reach maturity respectively. Sweet corn crop planted on June 19 planting minimum days to reach these stages. This variation reflects the optimum light and temperature during maturity period of crop sown on March 29 to April 15 might have prolonged the vegetative phase. Whereas weather condition particularly cloudy days and intensive rains might have forced the plants to enter into reproductive phase early thus resulting in shorter growth period and the plant do not get enough time for complete maturity during delayed planting (Azadbakht et al., (2012) and Ramachandrudu et al., (2013).

\section{COB Characteristics}

Among all the cultivars, Misthi produced cobs of maximum length of $15.89 \mathrm{~cm}$ followed by Sugar-75 $(15.07 \mathrm{~cm})$ and Gold star $(14.64 \mathrm{~cm})$ in the descending order of cob lengths. Cob girth values for different cultivars followed the similar numerical order as was recorded in case of cob length. Cultivar Misthi recorded maximum cob girth of $14.29 \mathrm{~cm}$ and was observed to be significantly superior to Sugar -75 with $13.30 \mathrm{~cm}$ and Gold star with 12.64 $\mathrm{cm}$ cob girths in the descending order of magnitude and these two latter cultivars in turn did not differ statistically from one another. There was non-significant influence of sweet corn cultivars on the number of grain rows per cob. Misthi with highest number of grain rows of 13.29 per cob was found superior followed by Sugar-75 with 12.53 and
Gold star with 11.85 grain rows per cob. Data presented in table 3 reveals that among the sweet corn cultivars significantly higher number of grains per cob row were recorded with cultivar Misthi (19.71) which were statistically at par with Cultivar Sugar -75 (18.78) and both of these cultivars realized significantly higher number of grains per cob row than cultivar Gold star (16.00). The cob number per plant is a fundamental factor to judge yield of corn plant. Among the cultivars maximum number of cobs per plant (1.14) was recorded by cultivar Misthi which was found to be statistically at par with Sugar75(1.13) and significantly superior than Gold star (1.05) also produced statistically equal cobs per plant with Sugar-75. Non-significant effect of cultivars was seen on the fresh cob weight of sweet corn, though some numerical variations have been observed among them. Lowest fresh cob weight was recorded for Gold star (108.63 g) while the highest fresh cob weight was recorded for Misthi (117.91g) followed by Sugar-75(110.95 g), respectively. A variation in cob characteristics was observed among the different cultivars of sweet corn (Table 3). Among the cob characteristics significant differences in respect of cob girth was observed among the cultivars and was might be regarded due to the genetic character of the variety (Konuskan (2000), Gozubenli et al., (2001).

Significant variation was recorded for cob length of sweet corn under different planting times. Maximum cob length of $18.46 \mathrm{~cm}$ was recorded for crop sown on April 15 which was statistically similar with March 29 and April 30 plantings with cob lengths of $17.52 \mathrm{~cm}$ and $17.22 \mathrm{~cm}$, respectively. May 15 and May 30 planting dates with 13.82 and $13.50 \mathrm{~cm}$ cob lengths were found statistically superior than the June 19 planting which produced significantly smaller cobs with cob length of $10.69 \mathrm{~cm}$ than all the planting dates. 
Table.1 Effect of cultivars and planting times on growth stages of sweet corn

\begin{tabular}{|c|c|c|c|c|c|c|c|c|c|c|c|c|}
\hline \multirow[b]{2}{*}{ Treatments } & \multicolumn{4}{|c|}{ Plant height (cm) } & \multicolumn{4}{|c|}{ Leaf area index } & \multicolumn{4}{|c|}{ Dry matter accumulation (g/plant) } \\
\hline & 30 DAS & 60 DAS & $\begin{array}{c}90 \\
\text { DAS }\end{array}$ & $\begin{array}{l}\text { At } \\
\text { harvest }\end{array}$ & $\begin{array}{c}\text { 30 } \\
\text { DAS }\end{array}$ & 60 DAS & 90 DAS & $\begin{array}{l}\text { At } \\
\text { harvest }\end{array}$ & $\begin{array}{c}\text { 30 } \\
\text { DAS }\end{array}$ & $\begin{array}{c}60 \\
\text { DAS }\end{array}$ & $\begin{array}{c}90 \\
\text { DAS }\end{array}$ & $\begin{array}{l}\text { At } \\
\text { harvest }\end{array}$ \\
\hline \multicolumn{13}{|l|}{ Cultivars } \\
\hline Misthi & 70.21 & 161.70 & 180.56 & 179.69 & 0.69 & 3.93 & 3.77 & 3.66 & 3.69 & 22.58 & 72.46 & 146.19 \\
\hline Sugar -75 & 68.80 & 161.12 & 180.52 & 179.47 & 0.66 & 3.86 & 3.74 & 3.53 & 3.53 & 19.91 & 71.12 & 145.33 \\
\hline Gold star & 67.89 & 161.02 & 176.79 & 175.51 & 0.64 & 3.78 & 3.57 & 3.49 & 3.48 & 17.14 & 68.59 & 142.70 \\
\hline $\mathrm{SEm} \pm$ & 0.80 & 1.53 & 2.04 & 2.19 & 0.02 & 0.18 & 0.15 & 0.11 & 0.38 & 1.56 & 1.28 & 1.37 \\
\hline $\mathrm{CD}(5 \%)$ & NS & NS & NS & NS & NS & NS & NS & NS & NS & NS & NS & NS \\
\hline \multicolumn{13}{|c|}{ Planting times } \\
\hline March 29 & 76.92 & 182.71 & 203.37 & 202.06 & 0.69 & 4.28 & 4.00 & 3.93 & 4.30 & 26.05 & 85.91 & 163.11 \\
\hline April 15 & 77.87 & 192.52 & 211.42 & 210.81 & 0.71 & 4.38 & 4.08 & 3.98 & 4.33 & 28.10 & 88.40 & 166.25 \\
\hline April 30 & 75.34 & 180.38 & 200.87 & 199.72 & 0.68 & 4.25 & 3.99 & 3.88 & 4.29 & 25.00 & 80.37 & 158.23 \\
\hline May 15 & 65.21 & 161.48 & 174.12 & 172.89 & 0.67 & 3.60 & 3.58 & 3.39 & 3.20 & 17.00 & 68.00 & 144.15 \\
\hline May 30 & 65.15 & 141.95 & 163.47 & 162.47 & 0.62 & 3.52 & 3.54 & 3.37 & 3.19 & 15.00 & 60.75 & 141.75 \\
\hline June 19 & 53.30 & 108.62 & 122.51 & 121.39 & 0.61 & 3.10 & 2.97 & 2.81 & 2.10 & 8.10 & 40.91 & 94.95 \\
\hline $\mathrm{SEm} \pm$ & 3.24 & 4.22 & 4.30 & 4.32 & 0.04 & 0.14 & 0.13 & 0.15 & 0.36 & 2.09 & 2.82 & 2.89 \\
\hline $\mathrm{CD}(5 \%)$ & 9.36 & 12.20 & 12.43 & 12.48 & NS & 0.41 & 0.39 & 0.44 & 1.04 & 6.05 & 8.16 & 8.37 \\
\hline
\end{tabular}


Int.J.Curr.Microbiol.App.Sci (2017) 6(10): 2971-2985

Table.2 Effect of cultivars and planting times on phenological stages of sweet corn

\begin{tabular}{|c|c|c|c|c|c|}
\hline \multirow[b]{2}{*}{ Treatments } & \multirow{2}{*}{ Emergence count (\%) } & \multicolumn{4}{|c|}{ Days taken to } \\
\hline & & Emergence & $50 \%$ tasseling & $50 \%$ silking & $\begin{array}{l}\text { Harvest } \\
\text { maturity }\end{array}$ \\
\hline \multicolumn{6}{|l|}{ Cultivars } \\
\hline Misthi & 80.03 & 4.66 & 54.83 & 60.71 & 94.24 \\
\hline Sugar -75 & 66.69 & 4.66 & 54.47 & 60.32 & 93.10 \\
\hline Gold star & 73.36 & 5.38 & 53.74 & 60.21 & 91.55 \\
\hline $\mathrm{SEm} \pm$ & 2.10 & 0.18 & 0.13 & 0.15 & 0.16 \\
\hline $\mathrm{CD}(5 \%)$ & 8.24 & NS & 0.54 & NS & 0.63 \\
\hline \multicolumn{6}{|c|}{ Planting times } \\
\hline March 29 & 81.36 & 5.77 & 56.31 & 61.93 & 94.67 \\
\hline April 15 & 82.69 & 5.00 & 55.62 & 61.79 & 94.57 \\
\hline April 30 & 78.69 & 4.66 & 55.45 & 61.50 & 94.26 \\
\hline May 15 & 71.36 & 4.33 & 53.35 & 59.62 & 92.47 \\
\hline May 30 & 76.69 & 5.22 & 53.15 & 59.60 & 92.41 \\
\hline June 19 & 49.35 & 4.44 & 52.22 & 58.00 & 89.40 \\
\hline $\mathrm{SEm} \pm$ & 8.24 & 0.18 & 0.30 & 0.23 & 0.27 \\
\hline $\mathrm{CD}(5 \%)$ & 6.71 & 0.54 & 0.87 & 0.68 & 0.78 \\
\hline
\end{tabular}


Table.3 Effect of cultivars and planting time on cob characteristics and cob yield of sweet corn

\begin{tabular}{|c|c|c|c|c|c|c|}
\hline Treatments & $\begin{array}{l}\text { Length of cob } \\
(\mathrm{cm})\end{array}$ & $\begin{array}{c}\text { Girth of } \\
\text { Cob }(\mathrm{cm})\end{array}$ & $\begin{array}{l}\text { No. of grain } \\
\text { rows/cob }\end{array}$ & $\begin{array}{c}\text { No. of } \\
\text { grains/cob } \\
\text { row }\end{array}$ & $\begin{array}{c}\text { No. of } \\
\text { cobs/ plant }\end{array}$ & $\begin{array}{c}\text { Grain yield } \\
\text { (t/ha) }\end{array}$ \\
\hline \multicolumn{7}{|l|}{ Cultivars } \\
\hline Misthi & 15.89 & 14.29 & 13.29 & 19.71 & 1.14 & 2.20 \\
\hline Sugar -75 & 15.07 & 13.30 & 12.53 & 18.78 & 1.13 & 1.74 \\
\hline Gold star & 14.64 & 12.64 & 11.85 & 16.00 & 1.05 & 1.57 \\
\hline $\mathrm{SEm} \pm$ & 0.84 & 0.15 & 0.84 & 0.60 & 0.02 & 0.09 \\
\hline $\mathrm{CD}(5 \%)$ & NS & 0.68 & NS & 2.32 & 0.08 & 0.37 \\
\hline \multicolumn{7}{|l|}{ Planting times } \\
\hline March 29 & 17.52 & 15.07 & 14.07 & 17.46 & 1.22 & 2.31 \\
\hline April 15 & 18.46 & 15.17 & 14.10 & 17.54 & 1.22 & 2.39 \\
\hline April 30 & 17.22 & 14.95 & 13.98 & 17.27 & 1.20 & 2.23 \\
\hline May 15 & 13.82 & 11.97 & 11.86 & 18.98 & 1.00 & 1.81 \\
\hline May 30 & 13.50 & 11.95 & 11.32 & 19.44 & 1.00 & 1.72 \\
\hline June 19 & 10.69 & 11.34 & 10.02 & 18.28 & 1.00 & 0.56 \\
\hline $\mathrm{SEm} \pm$ & 0.47 & 0.24 & 0.47 & 0.58 & 0.04 & 0.14 \\
\hline $\mathrm{CD}(5 \%)$ & 1.28 & 0.61 & 1.36 & NS & 0.12 & 0.41 \\
\hline
\end{tabular}


Table.4 Effect of cultivars and planting times on NPK uptake by sweet corn crop at maturity of sweet corn

\begin{tabular}{|c|c|c|c|c|c|c|c|c|c|}
\hline \multirow[t]{2}{*}{ Treatment } & \multicolumn{3}{|c|}{$\mathbf{N}(\mathbf{k g} / \mathrm{ha})$} & \multicolumn{3}{|c|}{ P (kg/ha) } & \multicolumn{3}{|c|}{ K(kg/ha) } \\
\hline & Grain & Stover & Total & Grain & Stover & Total & Grain & Stover & Total \\
\hline \multicolumn{10}{|l|}{ Cultivars } \\
\hline Misthi & 33.36 & 44.76 & 78.12 & 8.23 & 12.05 & 20.28 & 9.61 & 79.55 & 89.16 \\
\hline Sugar -75 & 27.51 & 38.60 & 66.11 & 6.18 & 10.29 & 16.47 & 7.83 & 67.97 & 75.80 \\
\hline Gold star & 25.05 & 37.44 & 62.50 & 5.78 & 10.06 & 15.85 & 7.34 & 65.16 & 72.50 \\
\hline $\mathrm{SEm} \pm$ & 1.86 & 2.95 & 4.68 & 0.84 & 1.10 & 1.40 & 0.56 & 4.86 & 5.37 \\
\hline $\mathrm{CD}(5 \%)$ & NS & NS & NS & NS & NS & NS & NS & NS & NS \\
\hline \multicolumn{10}{|c|}{ Planting time } \\
\hline March 29 & 35.34 & 48.12 & 83.46 & 8.26 & 12.68 & 20.94 & 10.21 & 85.31 & 95.52 \\
\hline April 15 & 35.92 & 50.28 & 86.20 & 8.22 & 13.15 & 21.38 & 10.44 & 89.19 & 99.64 \\
\hline April 30 & 34.62 & 46.40 & 81.03 & 7.93 & 11.32 & 19.25 & 9.76 & 82.17 & 91.94 \\
\hline May 15 & 29.34 & 39.13 & 68.47 & 6.52 & 10.99 & 17.51 & 8.41 & 68.23 & 76.64 \\
\hline May 30 & 27.34 & 37.44 & 64.79 & 6.48 & 10.45 & 16.93 & 8.05 & 65.34 & 73.39 \\
\hline June 19 & 9.27 & 20.22 & 29.49 & 2.97 & 6.21 & 9.19 & 2.67 & 35.10 & 37.78 \\
\hline $\mathrm{SEm} \pm$ & 2.68 & 3.08 & 5.18 & 0.48 & 1.64 & 1.64 & 0.68 & 5.33 & 5.86 \\
\hline $\mathrm{CD}(5 \%)$ & 7.75 & 8.92 & 14.96 & 1.39 & NS & 4.76 & 1.97 & 15.40 & 16.93 \\
\hline
\end{tabular}


Cob girth data at harvest maturity indicates that cob girth decreased with each successive delay in planting time after April 15 sowing wherein June 19 sown crop produced cobs with minimum cob girth. Maximum cob girth of $15.17 \mathrm{~cm}$ was recorded with April 15 planted crop which was statistically at par with March 29 with $15.07 \mathrm{~cm}$ and April 30 sown crop with $14.95 \mathrm{~cm}$ of cob girth. May 15 and May 30 sown crops with $11.97 \mathrm{~cm}$ and $11.95 \mathrm{~cm}$ cob girths were found statistically at par with each other but were significantly superior to June 19 planting date.

April 15 recorded the highest number of grain rows (14.10) per cob which were statistically at par with grain rows recorded for March 29 (14.07) and April 30 (13.98) planting dates.

May15 and May 30 planting dates being statistically similar recorded 11.86 and 11.32 numbers of grain rows per cob, respectively, and these two planting dates in turn differed significantly from June 19 sown crop which recorded 10.02 grain rows per cob.

Non-Significant differences in number of grains per cob row were recorded for different planting times as is depicted in table 3 However, numerically highest number of grains per cob row were recorded with May 30 planting (19.44) followed by 18.98, 18.28, 17.54, 17.46 and 17.27 as evidenced for May 15, May 30, April 15, March 29 and April 30 planting dates in the decreasing order of grains per cob row, respectively.

Sweet corn sown on March 29 and April 15 each produced maximum number of cobs per plant (1.22) and these were found statistically at par with April 30 (1.20) planting. Earlier sowings produced significantly higher number of cobs per plant as compared to later sowings of May15, May 30 and June 19 which remained statistically alike with each other bearing 1.0 cob per plant.
April 15 produced cobs with maximum fresh weight $(\mathrm{g})(133.86 \mathrm{~g})$ followed by statistically similar fresh cob weight realized under March 29(131.38g) and April 30 (123.99g) planting dates and all these dates recorded their significant superiority in this parameter over all the other sowing dates. May 15 and May 30 planting dates being statistically at par in fresh cob weights of $103.98 \mathrm{~g}$ and $101.43 \mathrm{~g}$, respectively were regarded more significantly superior than June 19 sown crop which produced fresh cobs of lowest weight (80.33 g).

The highest value of cob characteristics viz., length of cob, cob girth, number of grains row per cob, number of grains per cob were observed during April 15 planting date and this might be due better crop growth. The timely set sink in conjugation with accumulated and better translocation of photosynthates from source to sink for longer period might have been responsible for cobs with greater length and girth which in turn accounted for the higher grain number The reduction of number of grains per cob row in June 19 planting date might be due to reduced photosynthesis and limitations of photosynthetic materials during the grain filling period which reduced the number of grains at the top of the cob in June 19 sown crop. Also the cob girth might be decreased in the June sown crop due to pollination and fertilization problems. Oktem et al., (2004) and Farsiani et al., (2011)

\section{Grain yield}

Grain yield is the product of all the yield contributing factors. Data presented in table 4 and depicted in table 3 reveals significant influence of the sweet corn cultivars on grain yield. Cultivar Misthi recorded significantly highest grain yield of $2.206 \mathrm{t} / \mathrm{ha}$ which was significantly superior to cultivars Sugar-75 and Gold star which recorded 1.746t/ha and 
1.5.75t/ha of grain yields, respectively. Between Sugar-75 and Gold star, though cultivar Sugar-75 recorded higher grain yield than Gold star but both of these cultivars were observed to be statistically similar recording grain yields and the per cent increase in grain yield recorded by Misthi over Sugar-75 and Gold star was to the tune of 26.34 and 40.06 . Genetically different varieties significantly differed in their grain yield performance in corn was also reported by Khan et al., (2009).

Planting times also significantly influenced the grain yield of sweet corn as presented in table 14. The highest grain yield was recorded when sowing was done on April $15^{\text {th }}$ with grain yield of $2.395 \mathrm{t} / \mathrm{ha}$ statistically at par with grain yield realized with March $29^{\text {th }}$ (2.315 t/ha) and April $30^{\text {th }}$ plantings (2.234 t/ha). The grain yield recorded with May $15^{\text {th }}$ $(1.813 \mathrm{t} / \mathrm{ha})$ sowing was also found statistically comparable to May $30^{\text {th }}(1.729$ t/ha) planting dates and significantly lowest yields $(0.569 \mathrm{t} / \mathrm{ha})$ were obtained withJune $19^{\text {th }}$ planting. The range of per cent increase in yield of significantly highest but statistically comparable planting dates of April $15^{\text {th }}$, March $29^{\text {th }}$ and April $30^{\text {th }}$ over May $15^{\text {th }}$, May $30^{\text {th }}$ and June $19^{\text {th }}$ were to the extent of $32.10-$ 23.22, 38.51-29.20 and 320.91-292.61, respectively. This was might be due to the fact that the $15^{\text {th }}$ April sown crop got sufficient time for proper plant growth under suitable climatic conditions in comparison to late sowings and also early planting in spring causes encountering of grain formation and filling stages with long days and maximum energy needed to photosynthesis results in higher yields in comparison to late sowing i.e. June $19^{\text {th. }}$.

\section{NPK uptake}

Among the sweet corn cultivars, though statistically insignificant but the highest N,P and $\mathrm{K}$ uptake in grains, stover as well as total of $\mathrm{N}, \mathrm{P}$ and $\mathrm{K}$ uptakes in grains and stover with the values of $33.36,44.76,78.12$., $8.23,12.05,20.28 ., 9.61,79.55,89.16 \mathrm{~kg} / \mathrm{ha}$, respectively were recorded by cultivar Misthi followed by Sugar-75 and Gold star cultivars with 27.51,38.60.66.11., 6.18, 10.29, 16.47, $7.83,67.97,75.80 \mathrm{~kg} / \mathrm{ha}$ of $\mathrm{N}, \mathrm{P}, \mathrm{K}$ uptakes in grains, stover and grains and stover together, respectively (Table 4). The pooled N, P, and $\mathrm{K}$ uptake was in the order Misthi followed by Sugar-75 and Gold star. The cultivar wise differences in uptake pattern may be ascribed to their differential root geometry and concomitant nutrient mobilization capacity of the root exudates (Prathyusha et al., 2014).

Regarding uptake of $\mathrm{N}, \mathrm{P}$ and $\mathrm{K}$ in grains, stover and grains and stover both under the influence of planting times exhibits that except for $\mathrm{P}$ uptake in stover which also had the same numerical trend as were observed for other nutrients, all the planting dates significantly influenced the uptake of N, P and $\mathrm{K}$ in grains, stover as well as grains and stover together. Planting of April 15 removed highest amount of $\mathrm{N}, \mathrm{P}$ and $\mathrm{K}$ through grains, stover and grains and stover together with their respective values of $35.92,50.28,86.20$, $8.22,13.15,21.38$., 10.44, 89.19,99.64 kg/ha. It was followed by plantings of 29 March, 30 April and 15 May which in turn was statistically at with the planting of May 30 in removing $\mathrm{N} \quad(35.34, \quad 48.12,83.46$., $34.62,46.40,81.03 ., 29.34,39.13,68.47 \mathrm{~kg} / \mathrm{ha})$ and $\mathrm{K}(10.21,85.31,95.52 ., 9.76,82.17,91.94$, $8.41,68.23,76.64 \mathrm{~kg} / \mathrm{ha}$ ) in grains, stover and grains and stover combined where as in case of $\mathrm{P}$ uptake in grains, first three sowing dates removed statistically same amount of $\mathrm{P}$ followed by May 15 and 30 sowings which also removed same quantity of P. June 19 planting, however, failed to uptake significant amount of nutrients as compared to all the other sowing dates and was regarded as inferior in removal of nutrients. This might be attributed to higher dry matter and biological 
yield production which enhance the nutrient content in the vegetative part and translocating them in a considerable fraction to the cobs as well as high per cent $\mathrm{N}, \mathrm{P}, \mathrm{K}$ content in grain and stover. Whereas significantly lowest $\mathrm{N}, \mathrm{P}, \mathrm{K}$ uptake was recorded in June 19 planting date. This might be due to the fact that less translocation of photosynthates from source to sink due to shorter reproductive phase. Mukherjee (2012).

\section{References}

Ayub, M., R. Mehmood, A. Tanveer and I. Ahmad 1998. Fodder yield and quality of four cultivars of maize under different methods of sowing. Pakistan Journal of Biological Science. 1(3): 232-234.

Azadbakht, A., Azadbakht, G., Nasrollahi, H. and Bitarafan,Z.(2012) Evaluation of Different Planting Dates Effect on Three Maize Hybrids in Koohdasht Region of Iran. International Journal of Science and Advanced Technology 2:34-38.

Douglass S.K., Juvik J.A., Splittstoesser W.E. 1993. Sweet corn seedling emergence and variation in kernel carbohydrate reserve. Seed Science and Technology. 21: $433-445$.

Farsiani, A., Ghobadi, M.E and Honarmand S.J.2011. The effect of water deficit and sowing date on yield components and seed sugar contents of sweet corn ( $\mathrm{Zea}$ Mays L.). African Journal of Agricultural Research 6 (26) 57695774.

Gozubenli, H.,Ulger,A.C. and Sensor.,O.2001.The effect of different nitrogen doses on grain field and yield related characters of some genotypes grown as second crop.Agric.Fac.,16:3948.
Gracia, A.G.Y., Guerra, L.C.and Hoogenboom, G. 2009. Impact of planting date and hybrid on early growth of sweet corn. Agronomy Journal, 101:193-200.

Kara, B. 2011.Fresh ear yield and growing degree -days of sweet corn in different sowing dates in south-western Anatolia region. Turkish Journal of Field Crops, 16(2): 166-171.

Khan, Z.H., Khalil, S.K., Farhatullah, Khan, M.Y., Israr, M., and Basir, A.2011.Selecting optimum planting date for Sweet Corn in Peshawar Pakistan. Sarhad Journal of Agriculture.27 (3):341-347.

Khan, Z.H., Khalil, S.K., Nigar, S., Khalil, I., Haq, I., Ahmad, I., Ali, A. and Khan, M.Y. 2009. Phenology and yield of sweet corn landraces influenced by planting dates. Sarhad Journal of Agriculture, 25(2): 153-157.

Konuskan, O., 2000. Effects of plant density on yield and yield related characters of some maize hybrids grown in hardy conditions as $2^{\text {nd }}$ crop. M.sc. Thesis, Science Institute. M.K.U., pp:71

Kwabiah, A.B. 2004. Growth and yield of sweet corn (Zea Mays L.) cultivars in response to planting date and plastic mulch in a short season environment. Scientia Horticulturae, 102: 147-166.

Mokhtarpour, H. Feyzbaksh, T. Mossavat and Pourfarid.2013.Effects of sowing dates and planting density on Qualititative and Quantitative yield of Sweet corn Forage in Summer sowing. Asian Journal of Experimental Biology(4)251255.

Mukerjee 2012. Effect of different dates on growth and yield of wheat (Triticum aestivium) cultivars under mid hill situation of west Bengal. Indian Journal of Agronomy 57(2):152-156

Nielsen, R.L., Thomison, P.R., Brown, G.A., Halter, A.L., Wells, J. and 
Wuethrich,K.L. 2002. Delayed planting effects on flowering and grain maturation of dent corn. Agronomy Journal, (94):549-558.

Oktem, A., 2000 Determination of Sowing Dates of Corn (Zea Mays L.saccharata Sturt.) under dry land Conditions. Turkish Journal of Agriculture and Forestry. 21, 65-71.

Oktem. A., Oktem, A.G., and Coskun, Y.Y 2004 Determination of Sowing Dates of Sweet Corn (Zea Mays L.saccharata Sturt.) under Sanliurfa Conditions. Turkish Journal of Agriculture and Forestry. 28:83-89.

Otegui, M.E., Nicolini, M.G., Ruiz, R.A., and Dodds, P.A., 1995. Sowing date effects on grain yield components for different Maize genotypes. Agronomy Journal 87, 29-33.

Prathyusha, C., Hemalatha, S. Rao, P.V. Jayasree, G. 2014. Nitrogen response, nutrient uptake by the crop and postharvest soil fertility status in speciality corn as influenced by nitrogen fertilization under pongamia + maize agri. Journal of Science (4)170-173.

Ramachandrudu, K., Thangam, M. and Korikanthimath, V.S. 2013. Performance of sweet corn varieties under tropical conditions of Goa. Indian
Journal of Horticulture 70(3) 387-391. Ramankutty, N., Foley, J.A., Norman, J. and McSweeney,K. 2002. The global distribution of cultivable lands: Current patterns and sensitivity to possible climate change. Global Ecology Biogeography. 11:377-392.

Ramezani, M., R. Rezaie, S. Abandani, H. R. Mobasser and E. Amiri 2011. Effects of row spacing and plant density on silage yield of corn (Zea maysL.cv.sc704) in two plant pattern in North of Iran.African Journal of. Agricultural. Research. 6(5): 1128-1133.

Ritchie S.W., Kanway, J.J and Benson, G.D.1989. How corn plant develops. Special report no.48.Lower state University of Science and Technology Cooperative Extension Service Ames, Lowa. Reprinted July 1959.

Swanson, S.P. and W.W. Wilhelm. 1996. Planting dates and residue rate effects on growth, portioning, and yield of corn. Agronomy Journal. 88: 205-210.

Znidarcic, D., Ban.D., Silvana.A., Oplanic, M.,and Koncar.A.B.2008. Yield and quality of sweet corn (Zea mays L. var. saccharata corn.) cultivars grown on different soil types.Cereal Research communication. Vol. (36).

\section{How to cite this article:}

Monika Banotra, B.C. Sharma, Brij Nandan, Akhil Verma, I.A. Shah, Rakesh Kumar, Vikas Gupta and Tundup Namgial. 2017. Growth, Phenology, Yield and Nutrient Uptake of Sweet Corn as Influenced by Cultivars and Planting Times under Irrigated Subtropics of Shiwalik Foot Hills. Int.J.Curr.Microbiol.App.Sci. 6(10): 2971-2985. doi: https://doi.org/10.20546/ijcmas.2017.610.351 